\title{
Evaluating of the spatial heterogeneity of soil loss tolerance and its effects on erosion risk in the carbonate areas of southern China
}

\author{
Yue $\mathbf{L i}^{1,2}$, Xiao Yong Bai ${ }^{1,2,4}$, Shi Jie Wang ${ }^{1,2}$, Luo Yi Qin ${ }^{1,2}$, Yi Chao Tian ${ }^{1,3}$, and Guang Jie Luo ${ }^{1,3}$ \\ ${ }^{1}$ State Key Laboratory of Environmental Geochemistry, Institute of Geochemistry, Chinese Academy of Sciences, \\ Guiyang, Guizhou, 550002, PR China \\ ${ }^{2}$ Puding Comprehensive Karst Research and Experimental Station, Institute of Geochemistry, CAS and Science and \\ Technology Department of Guizhou Province, Puding, Guizhou, 562100, PR China \\ ${ }^{3}$ Graduate School of Chinese Academy of Sciences, Beijing 100029, PR China \\ ${ }^{4}$ Institute of Mountain Hazards and Environment, Chinese Academy of Sciences,Chengdu, Sichuan, 610041, PR China \\ Correspondence to: Xiao Yong Bai (baixiaoyong@126.com)
}

Received: 5 November 2016 - Discussion started: 21 December 2016

Revised: 11 April 2017 - Accepted: 21 April 2017 - Published: 29 May 2017

\begin{abstract}
Soil loss tolerance ( $T$ value) is one of the criteria in determining the necessity of erosion control measures and ecological restoration strategy. However, the validity of this criterion in subtropical karst regions is strongly disputed. In this study, $T$ value is calculated based on soil formation rate by using a digital distribution map of carbonate rock assemblage types. Results indicated a spatial heterogeneity and diversity in soil loss tolerance. Instead of only one criterion, a minimum of three criteria should be considered when investigating the carbonate areas of southern China because the "one region, one $T$ value" concept may not be applicable to this region. $T$ value is proportionate to the amount of argillaceous material, which determines the surface soil thickness of the formations in homogenous carbonate rock areas. Homogenous carbonate rock, carbonate rock intercalated with clastic rock areas and carbonate/clastic rock alternation areas have $T$ values of 20, 50 and $100 \mathrm{t} /\left(\mathrm{km}^{2} \mathrm{a}\right)$, and they are extremely, severely and moderately sensitive to soil erosion. Karst rocky desertification (KRD) is defined as extreme soil erosion and reflects the risks of erosion. Thus, the relationship between $T$ value and erosion risk is determined using KRD as a parameter. The existence of KRD land is unrelated to the $T$ value, although this parameter indicates erosion sensitivity. Erosion risk is strongly dependent on the relationship between real soil loss (RL) and $T$ value rather than on either erosion intensity or the $T$ value itself. If $\mathrm{RL}>>T$, then the erosion risk is high despite of a low RL. Conversely, if $T>>\mathrm{RL}$, then the soil is safe although RL is high. Overall,
\end{abstract}

these findings may clarify the heterogeneity of $T$ value and its effect on erosion risk in a karst environment.

\section{Introduction}

The fragile ecological environment of karst areas is closely related to surface soil (Keesstra et al., 2016; Novara et al., 2016; Comino et al., 2016; Li et al., 2016; Debolini et al., 2013). However, this factor is less associated with the total lack of inherent soil in such areas (Gessesse et al., 2014; Luo et al., 2016; Ligonja and Shrestha, 2013). Soil is continuously distributed through erosion, and rocky desertification landscapes are frequently generated (Molla and Sisheber, 2016; Tian et al., 2016; Bai et al., 2013). Determining soil loss tolerance ( $T$ value) is one of the most important criteria in controlling erosion and restoring ecosystems; therefore, this factor must be measured with accuracy. $T$ is expressed in terms of annual soil loss $\left(\mathrm{t} \mathrm{km}^{-2} \mathrm{a}\right)$ and reflects the maximum level of soil erosion that can occur while allowing the land to sustain an indefinite, economic level of crop productivity (Wischmeier and Smith, 1965). This value is an important criterion in determining the potential erosion risk of a particular soil and often serves as the ultimate erosion control criterion to preserve long-term soil productivity (Duan et al., 2012). Thus, a scientifically determined $T$ value is among the most significant aspects in planning soil erosion control on agricultural lands and other types of 
lands (Liu et al., 2003). The concept of this value was first proposed in the United States in 1956, and the top 10 influencing factors were identified for a particular soil. Although the determination of $T$ value is often modified, the soil formation rate remains a typical and necessary factor. Early researchers (Hays et al., 1941; Klingebiel, 1961; Pretorius and Cooks, 1989) generated empirical proofs to compute this value. In the 1980s, Fran Pierce suggested the use of a soil productivity model to calculate the $T$ value and initiated the quantitative study of this factor. Worldwide $T$ values obtained based on the soil productivity method range from 116 to $9300 \mathrm{t} /\left(\mathrm{km}^{2}\right.$ a) depending on the location (Pierce et al., 1983, 1984). In India, the default soil loss tolerance limit is set at $11.2 \mathrm{Mg} \mathrm{ha}^{-1} \mathrm{yr}^{-1}$ for soil conservation activities. Scholars who examined related topics suggested that criteria should be established to determine the $T$ value limits, and that these values should differ for each soil series (Bhattacharyya et al., 2008). William and Smith (1964) proposed a notion model of an estimated $T$ value in relation to the strength of both soil properties and soil formation rates (William and Smith, 1964). Skidmore (1982) improved the concept model and calculated this value using soil thickness instead of soil characteristics (Skidmore, 1982). Both high and low $T$ limits are incorporated in this approach. According to Bazzoffi (2009), the notion of tolerance erosion based on only soil productivity and soil reformation rate is declining, and the off-site effects of soil erosion should be considered. Therefore, he suggested expanding the concept of hydrogeological risk to soil erosion by implementing the notion of $T$ alongside a new concept, namely, the environmental risk of soil erosion. Scholars agree that soil loss should stabilize soil fertility and long-term soil productivity in addition to maintaining the balance between soil loss and soil formation rates (Pierce et al., 1983; Alexander, 1988). Purple soils (entisols) derived from limestone bedrock in China have faster formation rates than other soils. When exposed at the surface, the maximum weathering rate of this soil type is $15000 \mathrm{Mg} \mathrm{km}^{-2} \mathrm{yr}^{-1}$ (Nadalromero and Regüés, 2010). Purple soils are ideal for $T$ research conducted over a short period because of their high formation rates. In the carbonate mountain areas of southern China, soil thickness generally ranges from 30 to $50 \mathrm{~cm}$. Once the soil is lost, the underlying basement rock is exposed, and karst rocky desertification (KRD) land appears (Wang et al., 2004). This occurrence, which is caused by soil erosion, is among the most serious eco-environmental problems in this region. Mineralogical and geochemical studies indicate that soil layers are predominantly derived from residues (argillaceous material) that remain after the dissolution of the underlying carbonate rocks and of the thin argillaceous layers interbedded among these rocks (Wang et al., 1999; Pak et al., 2016). Owing to the low concentrations of acid-insoluble components, the volume of carbonate rocks tends to decrease sharply with the formation of weathering crusts. Highly pure carbonate rocks correspond to low acid-insoluble substance content; therefore, the weathering-pedogenesis of carbonate rocks is the most fundamental and common geological-geochemical process (Drever and Stillings, 1997; Liu et al., 2009). This process is also the main soil formation factor used in subtropical carbonate regions. The severity of soil erosion depends strongly on the soil formation rate, which is also dependent on the local geological setting. Therefore, the $T$ value in carbonate areas can be determined according to this rate. The objectives of this research are as follows: (1) discover the spatial heterogeneity and diversity of soil erosion tolerance in the carbonate areas of southern China and disprove the old "one region, one $T$ value" concept; and (2) propose a new viewpoint stating that in karst regions, a large soil erosion modulus does not correspond to severe soil erosion and clarify the heterogeneity of $T$ values and its effects on the erosion risk in karst environments.

\section{Study area}

The study area is located across the Yangtze River and Pearl River in south-western China. The approximate coordinates are $22^{\circ} 01^{\prime}-33^{\circ} 16^{\prime} \mathrm{N}$ and $98^{\circ} 36^{\prime}-116^{\circ} 05^{\prime} \mathrm{E}$. The area covers Guizhou, Yunnan, Guangxi Zhuang Autonomo, Hunan, Hubei, Sichuan, Chongqing Municipalities and Guangdong Province (Fig. 1). Moreover, the study area is one of the tropical moist and subtropical moist regions, and the annual average temperature is $11.0-19.0^{\circ} \mathrm{C}$. Considering the plenty rain, more than $80 \%$ of the area's average annual total precipitation is between 1100 and $1300 \mathrm{~mm}$. The quantity of rain throughout the seasons is uneven; more rainfall occurs in May-October, and the precipitation from June to August accounts for approximately half of the total. Carbonate rock covers an outcropped area of $522100 \mathrm{~km}^{2}$ from the Sinian to Triassic. The thick carbonate formation was deposited in the study area. Yunnan, Qianxi-Qiannan and western Guangxi are mainly covered with a thick layer of bare limestone, dolomite and limestone. North-eastern Guizhou, Chongqing, Hubei and Xiangxi trough valley areas are mainly composed of interbedded dolomite and clastic rocks. The middle part of Hunan, central Guilin area, south-eastern Guangxi and northern Guangdong are covered with carbonate rock. The west of Sichuan and Yunnan consist primarily of buried limestone. The south-western karst mountainous areas are characterized by limestone soil, and the distribution of this soil varies considerably. This area also contains inland plateau lands.

\section{Materials and methods}

\subsection{Construction of a carbonate rock assemblage distribution map}

A $1: 500000$ scale digital geological map is constructed to show the distribution of carbonate rock assemblage types 


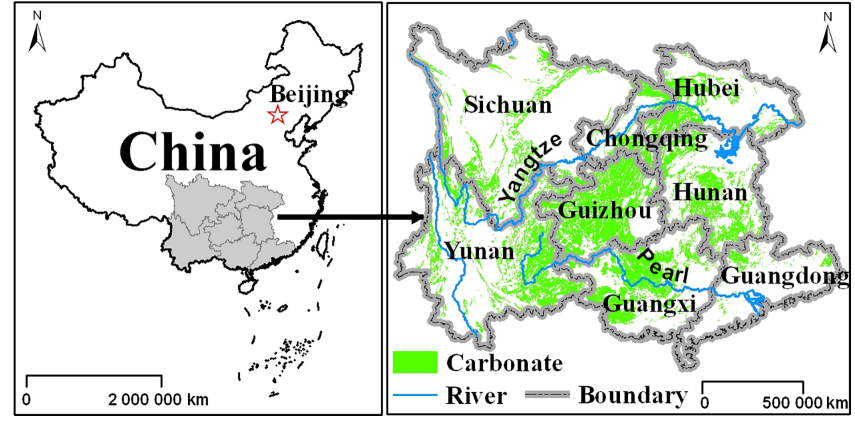

Figure 1. Map showing the location and distribution of carbonate regions in southern China.

in the carbonate areas of southern China. An officially published map is used as a data source.

The method of constructing a carbonate rock assemblage distribution map is identical to our previously used technique (Wang et al., 2004). The amount of argillaceous material in formations is an indicator that distinguishes rock assemblages because it indicates the surface soil thickness. Thus, assemblages can be divided into three types as follows.

1. Homogenous carbonate rock (HC): $>90 \%$ carbonate rock, $<10 \%$ argillaceous material and no clear clastic interbed. Based on the composition, $\mathrm{HC}$ can be categorized into three subtypes: homogenous limestone (HL), homogenous dolomite (HD) and mixed dolomite/limestone (HDL).

2. Carbonate rock intercalated with clastic rock (CI): 70 $90 \%$ carbonate rock, 10-30\% argillaceous material and has a clear clastic interbed. Based on composition, CI can be divided into two subtypes, namely, limestone interbedded with clastic rock (LI) and dolomite interbedded with clastic rock (DI).

3. Carbonate/clastic rock alternations (CA): 30-70 carbonate and $70-30 \%$ clastic rocks. Based on composition, CA can be categorized into two subtypes, namely, limestone/clastic rock alternations (LA) and dolomite/clastic rock alternations (DA).

The argillaceous material can be computed based on 5, 20 and $50 \%$ for $\mathrm{HC}, \mathrm{CI}$ and $\mathrm{CA}$. In addition, carbonate rock can be computed based on 95,80 and $50 \%$ for $\mathrm{HC}, \mathrm{CI}$ and CA.

This information is shown in Table 1.

\subsection{Method of computing soil information rate}

The soil information rate of carbonate rocks is related to temperature, precipitation, hydrology, vegetation and other environmental conditions. This rate changes annually, monthly, daily and even hourly on the same day (over daytime and night time). The average soil information rate can reflect the overall characteristics but does not represent the specific position and special time. The soil information rate ranges from $30.00-89.70 \mathrm{~mm} \mathrm{ka}^{-1}$ with a mean rate of $55.27 \mathrm{~mm} \mathrm{ka}^{-1}$ in the carbonate areas of southern China as per a long-term field observation. As per the results of an in-house laboratory investigation, the densities of calcite carbonatite and dolomite carbonatite are 2.75 and $2.86 \mathrm{t} \mathrm{m}^{-3}$. The soil formation rate of other rock types is $200 \mathrm{t} /\left(\mathrm{km}^{2}\right.$ a) ( $\mathrm{Li}$ et al., 2006), and the rates of different rock type assemblages serve as their $T$ values.

Specific $T$ value can be calculated with the following equation:

$T=v Q \rho C+R(1-C)$,

where $T$ is the soil loss tolerance $\left(\mathrm{t} \mathrm{km}^{-2} \mathrm{yr}^{-1}\right), v$ is the dissolution velocity of carbonate rocks $\left(\mathrm{m}^{3} \mathrm{~km}^{-2} \mathrm{yr}^{-1}\right), Q$ is the content of acid-insoluble components (\%), $\rho$ is the carbonate density $\left(\mathrm{t} \mathrm{m}^{-3}\right), C$ is the proportion of carbonate and $R$ is the soil formation rate of other rock types.

\subsection{Construction of a KRD land distribution map in Guizhou Province in 2000}

Based on the classification scheme shown in Table 2 and in combination with the corresponding $1: 100000$ scale digital land use maps, the human-computer interactive interpreting method is used to construct a $1: 100000$ scale digital hydrogeology, relief, soil distribution and karst rock desertification (KRD) land use maps in the year 2000 from the Landsat images.

Guizhou Province has an area of $176000 \mathrm{~km}^{2}$ and lies in the centre of the south-eastern Asian karst zone (Fig. 2). Carbonate rock is widespread and accounts for $62 \%$ of the total land area. KRD is a serious problem in this region (Wang et al., 2004). Therefore, the relationship between KRD and $T$ value is determined using Guizhou Province as an example. As per this classification, a $1: 100000$ scale digital map that shows KRD land distribution overlaps with a $T$ distribution map is developed. The spatial relationship between these two maps is then analysed.

\section{Results and discussion}

\subsection{Spatial distribution of carbonate rock assemblages}

As shown in Fig. 2a and Table 3, the total area is $527196 \mathrm{~km}^{2}$, of which 109416,108828 and $81772 \mathrm{~km}^{2}$ belong to Guizhou, Yunan and Guangxi, respectively. Carbonate is mainly concentrated in Guizhou, eastern Yunan, central and western Guangxi, western Hubei, southeastern Chongqing, southern Hunan, northern Guangdong and south-western Sichuan. HL covers $134996 \mathrm{~km}^{2}$ and is primarily distributed in western, southern and south-western Guizhou, eastern Yunan and western Guangxi. However, 
Table 1. Division of rock type assemblage.

\begin{tabular}{|c|c|c|}
\hline \multirow{6}{*}{$\begin{array}{l}\text { Carbonate } \\
\text { rocks }\end{array}$} & \multicolumn{2}{|c|}{$\begin{array}{l}\text { Continuity carbonate rocks assemblage } \\
\text { (Homogenous carbonate rock }>90 \% \text { ) }\end{array}$} \\
\hline & homogenous limestone & mixed dolomite/limestone \\
\hline & \multicolumn{2}{|c|}{$\begin{array}{l}\text { carbonate rock intercalated with clastic rock } \\
\text { (carbonate rock: } 70-90 \%)\end{array}$} \\
\hline & limestone interbedded with clastic rock & $\begin{array}{l}\text { dolomite interbedded } \\
\text { with clastic rock }\end{array}$ \\
\hline & \multicolumn{2}{|c|}{$\begin{array}{l}\text { carbonate/clastic rock alternations } \\
\text { (carbonate rock: } 30-70 \%)\end{array}$} \\
\hline & limestone/clastic rock alternations & dolomite/clastic rock alternations \\
\hline Clastic rocks & \multicolumn{2}{|c|}{ siliceous rock, metamorphic rock, magmatic rock } \\
\hline
\end{tabular}

Table 2. Classification criterion and characteristic code of KRD types (Hu et al., 2008).

\begin{tabular}{lrll}
\hline $\begin{array}{l}\text { Classification and code } \\
\text { of KRD type }\end{array}$ & $\begin{array}{r}\text { Proportion percentage } \\
\text { of bare rock }(\%)\end{array}$ & $\begin{array}{l}\text { Distribution character } \\
\text { of the exposed rock }\end{array}$ & $\begin{array}{l}\text { Colour of } \\
\text { the RS image }\end{array}$ \\
\hline No KRD (NKRD) & $<20$ & Star & Scarlet \\
Potential KRD (PKRD) & $20-30$ & Star, Line & Shocking pink \\
Present KRD (AKRD) & $>31$ & Patch & Pink, grey, white \\
\hline
\end{tabular}

Note: colours of the RS image displayed with Landsat TM bands 4, 3 and 2 are displayed as red, green and blue.

this limestone is slightly scattered in Hunan. HD covers $58723 \mathrm{~km}^{2}$ and is exposed in the form of elongated belts in various places; other assemblage types are scarce. HDL covers $63819 \mathrm{~km}^{2}$ and is mainly found in Guangxi and $\mathrm{Hu}-$ nan and northern central and southern Guizhou. LI covers $148577 \mathrm{~km}^{2}$ and is the most widespread type of carbonate rock. DI covers $22889 \mathrm{~km}^{2}$ and is chiefly detected in central Guizhou and south-western Sichuan. LA covers $55527 \mathrm{~km}^{2}$ and is mainly detected in southern Guizhou and western Hubei. Finally, DA covers only $42665 \mathrm{~km}^{2}$ and is primarily found in south-west Sichuan and eastern Yunan.

\subsection{Determination of $T$ value and assessment of soil erosion risk}

Figure $2 \mathrm{~b}$ shows the calculated $T$ values of different carbonate rock assemblages according to Eq. (1). The $T$ values in the HC, HL and HDL areas are 17.22, 17.51 and $17.36 \mathrm{t} /\left(\mathrm{km}^{2} \mathrm{a}\right)$, whereas the $T$ values in the LI and DI areas are 46.08 and $46.02 \mathrm{t} /\left(\mathrm{km}^{2} \mathrm{a}\right)$. The $T$ values in LA and DA areas are 103.80 and $107.95 \mathrm{t} /\left(\mathrm{km}^{2} \mathrm{a}\right)$. These values indicate the spatial heterogeneity in the carbonate areas of southern China; such heterogeneity is closely related to the amount of argillaceous material, which determines the surface soil thickness in the formations. The "one region, one $T$ value" concept cannot fully reflect the essence and the real circumstances in the area. This inadequacy may be attributed to the diverse results obtained by different researchers. An incor- rect value is typically obtained regardless of the calculated $T$ value, and three criteria should be considered instead of only one criterion.

The $T$ values of the HC, CI and CA areas are 20, 50 and $100 \mathrm{t} /\left(\mathrm{km}^{2} \mathrm{a}\right)$. These areas contain the least, lesser and great amounts of argillaceous materials, and thus are extremely, severely and moderately sensitive to soil erosion. Hence, the $T$ values in the carbonate areas of southern China are spatially heterogeneous (Table 4).

In addition, the $T$ values of limestone and dolomite have similar amounts of argillaceous material. However, according to the results of our in-house laboratory investigation (Zhang et al., 2007), the dissolution velocity of calcite is 16 times that of dolomite. These two types of mineral constituent rocks differ by 1.5-2 times both in in-house laboratory and field observations (Cao et al., 2009). In the same season and under similar spring conditions, the carbonate content of the dolomite area in the water exceeds that of the limestone area (Jiang et al., 1997). In terms of lithology, the dolomite voidage is uniform and dense; thus, the specific surface area of water-rock interaction can be increased. As a result, conditions are set for water retention and interaction time extension (Cao et al., 2009). Given its uniformity, dolomite weathering is extremely intense, induces the loosening and easy formation of storage cataclasites and establishes conditions for plant growth. Biological processes further accelerate the dissolution velocity. In addition, dolomite 

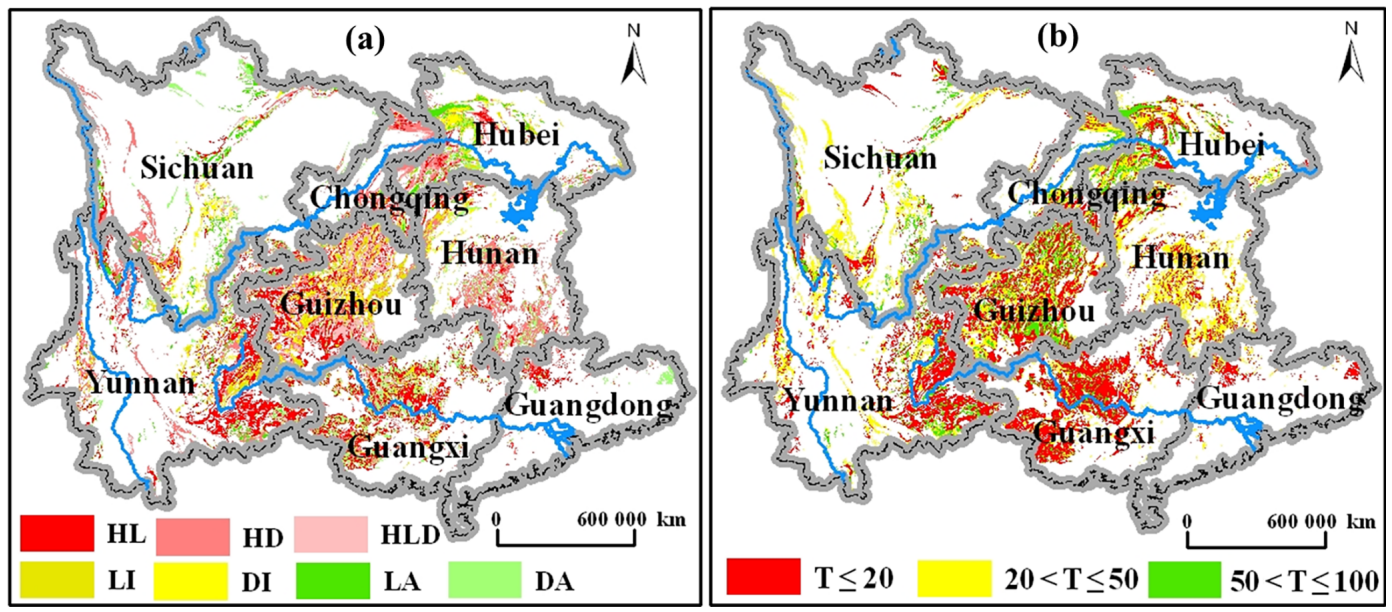

Figure 2. Distribution map of carbonate rock assemblage types (a) and $T$ value (b) in carbonate areas of southern China. Homogenous limestone is HL, homogenous dolomite is HD, mixed limestone/dolomite is HLD, limestone interbedded with clastic rock is LI, dolomite interbedded with clastic rock is DI, limestone/clastic rock alternations is LA, dolomite/clastic rock alternations is DA, soil loss tolerance is $\mathrm{T}$.

Table 3. Distribution areas of different carbonate rock assemblage types in carbonate areas of southern China $\left(\mathrm{km}^{2}\right)$.

\begin{tabular}{lrrrrrrrrr}
\hline & Chongqing & Guangdong & Guangxi & Guizhou & Hubei & Hunan & Sichuan & Yunan & Study area \\
\hline Total & 82400 & 179800 & 236300 & 176100 & 185900 & 211875 & 485000 & 394000 & 1951375 \\
Carbonate & 29896 & 10440 & 81772 & 109416 & 53146 & 65780 & 67918 & 108828 & 527196 \\
HL & 6722 & 4603 & 34309 & 30677 & 5184 & 9087 & 7579 & 36835 & 134996 \\
HD & 2474 & 0 & 3131 & 22991 & 10393 & 4101 & 3458 & 12175 & 58723 \\
HDL & 2006 & 3143 & 26162 & 3690 & 4694 & 12071 & 7484 & 4568 & 63819 \\
LI & 11114 & 2694 & 12355 & 19340 & 14641 & 35683 & 26085 & 26666 & 148577 \\
DI & 58 & 0 & 260 & 7210 & 2664 & 3193 & 7730 & 1774 & 22889 \\
LA & 6835 & 0 & 5517 & 25231 & 6374 & 483 & 1889 & 9197 & 55527 \\
DA & 687 & 0 & 38 & 276 & 9196 & 1161 & 13693 & 17613 & 42665 \\
\hline
\end{tabular}

releases abundant magnesium ions during the weatheringpedogenesis of carbonate rocks as its main contribution to the formation of clay mineral. By contrast, limestone cannot supply a sufficient amount of such ions. These phenomena accelerate the dissolution velocity of dolomite and supplement the deficiency. This mechanism may explain the similarity in the $T$ values of limestone and dolomite (Feng et al., 2013).

\subsection{Effect of $T$ value on karst rocky desertification}

As shown in Table 5, the AKRD land measured 18491, 10955 and $9456 \mathrm{~km}^{2}$ in the extremely, severely and moderately sensitive areas. KRD land is concentrated in the extremely sensitive area $(T=20)$ and covers over $47 \%$ of the total area in Guizhou Province. Of the total AKRD land, $28.16 \%$ is severely sensitive ( $T=50$ ), and $24.31 \%$ is moderately sensitive $(T=100)$.

These findings suggest that a low $T$ value corresponds to a large KRD area. The KRD land area is coherent in relation to the $T$ value criterion. Nonetheless, the relationship between
NKRD land and $T$ value is unchanged. Based on the information provided above, the areas of background value in different $T$ value regions $(T=20,50,100)$ were 57375,26558 and $25515 \mathrm{~km}^{2}$. The distribution area of KRD is strongly affected by the area of geological environment. During the Cretaceous Period of the Mesozoic Era, this area was a shallow marine sedimentary environment and experienced many transgressive and regressive phenomena, which were alternately caused by marine and continental sediments. The formation of a variety of rock types in Karst, Yanshan and Himalayan movements caused the deposition of Karst rock uplift to the surface and the formation of folds, faults and broken steep landform patterns. The development of rock and soil in Karst is slow, thereby resulting in the shallow soil layer, slow growth of vegetation and loss of soil. Therefore, the AKRD land area might not reflect the appearance of this land in different regions, although this area indicates the distribution situation.

Table 6 shows the generation of KRD land relative to the different regions that are sensitive to soil erosion. This oc- 
Table 4. Criteria of $T$ value and sensitivity of soil erosion in carbonate areas of southern China.

\begin{tabular}{lrrrr}
\hline $\begin{array}{l}\text { Carbonate rock } \\
\text { assemblages }\end{array}$ & $\begin{array}{r}T \text { value } \\
\mathrm{t} /\left(\mathrm{km}^{2} \mathrm{a}\right)\end{array}$ & $\begin{array}{r}\text { Area } \\
\left(\mathrm{km}^{2}\right)\end{array}$ & $\begin{array}{r}\text { Proportion } \\
(\%)\end{array}$ & $\begin{array}{r}\text { Sensitivity of } \\
\text { soil erosion }\end{array}$ \\
\hline Homogenous carbonate rock & 20 & 257538 & $48.85 \%$ & Severe \\
Carbonate rock intercalated with clastic rock & 50 & 171466 & $32.52 \%$ & Moderate \\
Carbonate/clastic rock alternations & 100 & 98192 & $18.63 \%$ & Low \\
\hline
\end{tabular}

Table 5. Karst rocky desertification area under different sensitivities.

\begin{tabular}{lrrr}
\hline & $\begin{array}{r}\text { AKRD } \\
\left(\mathrm{km}^{2}\right)\end{array}$ & $\begin{array}{r}\text { PKRD } \\
\left(\mathrm{km}^{2}\right)\end{array}$ & $\begin{array}{r}\text { NKRD } \\
\left(\mathrm{km}^{2}\right)\end{array}$ \\
\hline Moderate sensitivity & 9457 & 7889 & 8169 \\
Severe sensitivity & 10955 & 6004 & 9599 \\
Utmost sensitivity & 18491 & 17926 & 20957 \\
\hline
\end{tabular}

Note: karst rocky desertification (AKRD), potential karst rocky

desertification (PKRD) and no karst rocky desertification (NKRD).

Table 6. KRD area percentage under different sensitivities.

\begin{tabular}{lrrr}
\hline & $\begin{array}{rrr}\text { AKRD } \\
(\%)\end{array}$ & $\begin{array}{r}\text { PKRD } \\
(\%)\end{array}$ & $\begin{array}{r}\text { NKRD } \\
(\%)\end{array}$ \\
\hline Moderate sensitivity & 37.06 & 22.61 & 32.02 \\
Severe sensitivity & 41.25 & 22.61 & 36.14 \\
Utmost sensitivity & 32.23 & 31.24 & 36.53 \\
\hline
\end{tabular}

currence is maximized at 41.25, 37.06 and $32.23 \%$ in the severely, moderately and extremely sensitive areas. This finding confirms that the occurrence of AKRD land is unrelated to the $T$ value. In other words, this value is not the real factor that determines the KRD appearance in carbonate areas. Thus, the $T$ value cannot reflect the soil erosion risk although it reflects the sensitivity of soil erosion.

Erosion risk depends on the relationship between RL and $T$ value rather than on soil erosion intensity or $T$ value itself. If $\mathrm{RL}>>T$, then the risk is high but RL is low. Conversely, if $\mathrm{RL}<<T$, then the soil is safe but RL is high (Table 7).

The occurrence of KRD is highest in the severely sensitive area $(41.25 \%)$. This result indicates that RL is considerably greater than the $T$ value, and that the situation is extremely dangerous. However, these values do not necessarily imply that RL remains considerably smaller than $T$ value in the moderately and extremely sensitive areas. Conversely, the occurrences of KRD land are 37.06 and $32.23 \%$ in these areas; such values clearly indicate high degrees of soil erosion. Thus, the severely sensitive area is the most hazardous area.

\subsection{T value criteria in different regions}

$T$ values with reference to the different conditions of their respective regions are subsequently proposed to establish
Table 7. Criterion for risk assessment of soil erosion in carbonate areas of southern China.

\begin{tabular}{llll}
\hline Types & Range & RL/T value & Erosion risk grade \\
\hline Low & Above critical & $R>2$ & Utmost safety \\
& & $1.5<R \leq 2$ & Severe safety \\
& & $1<R \leq 1.5$ & Moderate safety \\
Moderate & Equal & $R=1$ & Critical point \\
High & Below critical & $0.5 \leq R<1$ & Utmost danger \\
& & $0.2 \leq R<0.5$ & Severe danger \\
& & $R<0.2$ & Moderate danger \\
\hline
\end{tabular}

an accurate $T$ value standard. The United States Department of Agriculture Soil Conservation Bureau established a systematic $T$ value system that ranged between 220 and $1120 \mathrm{t} /\left(\mathrm{km}^{2} \mathrm{a}\right)$ in 1973 . This standard is still being used at present. In central Africa, the sand and clay $T$ values are 150 and $180 \mathrm{t} /\left(\mathrm{km}^{2} \mathrm{a}\right)$. In Russia, a $T$ value range of $340-1090 \mathrm{t} /\left(\mathrm{km}^{2}\right.$ a) was reported, whereas a range of $450-$ $1120 \mathrm{t} /\left(\mathrm{km}^{2} \mathrm{a}\right)$ was established in India. In China, $T$ values of 1000,200 and $500 \mathrm{t} /\left(\mathrm{km}^{2} \mathrm{a}\right)$ are reported for the Loess Plateau, the phaeozem regions of north-eastern China and northern Rocky Mountain and the hilly red soil regions of southern China and south-western Rocky Mountain, respectively. In this work, the $T$ values in the $\mathrm{HC}, \mathrm{CI}$ and CA areas are 20, 50 and $100 \mathrm{t} /\left(\mathrm{km}^{2}\right.$ a) (Yang et al., 2004)

Some senior scholars and scientists conducted preliminary studies on soil erosion. Duan et al. (2012) modified soil productivity index model to calculate a quantitative $T$ value for different black soil species in the black soil region of northeastern China. The $T$ values of the 21 black soil species in the study area ranged from 68 to $358 \mathrm{t} /\left(\mathrm{km}^{2}\right.$ a) with an average of $141 \mathrm{t} /\left(\mathrm{km}^{2} \mathrm{a}\right)$. This average $T$ value is $29.5 \%$ less than the current national standard. The $T$ values of the three different soil subgroups in the study area are albic black soil, $106 \mathrm{t} /\left(\mathrm{km}^{2} \mathrm{a}\right)$; typical black soil, $129 \mathrm{t} /\left(\mathrm{km}^{2} \mathrm{a}\right)$; and meadow black soil, $184 \mathrm{t} /\left(\mathrm{km}^{2}\right.$ a) (Duan et al., 2012). Based on the soil nutrient balance and test data, Shui et al. (2003) suggested that soil loss tolerance in $Q_{2}$ red-clay-derived red earth should be lower than $300 \mathrm{t} /\left(\mathrm{km}^{2} \mathrm{a}\right)$. Yuan et al. (2005) determined the soil loss tolerance of less than $120 \mathrm{t} /\left(\mathrm{km}^{2} \mathrm{a}\right)$ in the hilly purple rock area in central Hunan (2005). Based on theoretical analysis, field examination and investigation, Chen et al. (2003) reported that the $200 \mathrm{t} /\left(\mathrm{km}^{2} \mathrm{a}\right)$ is the rational soil loss tolerance of sloping field in semi-arid hill-gully 
area of the Loess Plateau over a long period according to soil formation velocity, top soil nutrient balance, land productivity stability in sloping field, sediment transport tolerance of the Yellow River course and regional economic development (2003).

Some scholars conducted countless studies in karst areas. According to the corroded ratio and content rate of carbonate rocks, Chai (1989) calculated the estimated amount of soil loss tolerance at $68 \mathrm{t} /\left(\mathrm{km}^{2} \mathrm{a}\right)$ in the karst area of Guangxi Autonomous Region. Chen (1993) measured the accumulated and loss amounts of soil nutrient for the top layer soil in forest land and analysed the balance of NPK (nitrogen, phosphorus and potassium) and the rate of soil formation, which approached the amount of allowed soil loss. Under the upper reaches of the Changjiang River climatic conditions, the upper line of allowed soil loss is $50 \mathrm{t} /\left(\mathrm{km}^{2}\right.$ a) for developing soil from limestone, whereas $100 \mathrm{t} /\left(\mathrm{km}^{2}\right.$ a) for developing soil from non-carbonaceous rock. Wei (1996) reported that the $T$ values of the calcareous soil area in the karst area ranged from 0.522 to $1.285 \mathrm{t} /\left(\mathrm{km}^{2} \mathrm{a}\right)$; if the eluviation and normal erosion in soil-forming process were not considered, then the scope of the $T$ value ranges from 3.24 to $8.10 \mathrm{t} /\left(\mathrm{km}^{2} \mathrm{a}\right)$. However, the soil loss tolerance of some parts of the argillaceous limestone, such as the non-pure carbonate rocks, can be increased to $16.2-40.5 \mathrm{t} /\left(\mathrm{km}^{2} \mathrm{a}\right)$, and the upper line of soil allowed loss is $50 \mathrm{t} /\left(\mathrm{km}^{2}\right.$ a) for the karst area (Wei, 1996). Li (2006) reported that with $49.67 \mathrm{~mm} \mathrm{ka}^{-1}$ as the average weathering dissolving rate of carbonate rocks in Guizhou, the pedogenesis rates of different petrologic assemblages in carbonate area were calculated and used as the values of soil loss tolerance in carbonate areas. The soil loss tolerance in $\mathrm{HC}$ area was lower than $6.84,45.53$ in $\mathrm{CI}$ areas and $103.46 \mathrm{t} /\left(\mathrm{km}^{2} \mathrm{a}\right)$ in CA areas (2006).

In this study, $T$ value was calculated using digitaldistribution map of carbonate rock assemblage types based on the pedosphere system theory. Results indicated spatial heterogeneity and diversity in such values. The $T$ value is proportionate to the amount of argillaceous material, which determines the surface soil thickness in the formations of $\mathrm{HC}$ areas. The values are 20 and $50 \mathrm{t} /\left(\mathrm{km}^{2} \mathrm{a}\right)$ in CI areas and $100 \mathrm{t} /\left(\mathrm{km}^{2} \mathrm{a}\right)$ in carbonate/clastic rock alternation areas. Erosion risk is strongly dependent on the relationship between real soil loss (RL) and $T$ value rather than on either erosion intensity or the $T$ value itself. These findings may clarify the heterogeneity of $T$ value and its effect on erosion risk in a karst eco-environment. Hence, innovative technological assessment solutions are not required. In summary, this paper presents a method that provides experience and data for reference on the related research of soil erosion of karst landform areas of international counterparts. However, this study has limitations; it cannot fully consider the dry and wet deposition in atmosphere and the contribution of acid rain to soil forming rate. Such a restriction might affect the accuracy.

\section{Conclusions}

This study might clarify the heterogeneity of $T$ values and its effects on erosion risk in a karst eco-environment, providing an alternative to inventing innovative technological assessment solutions. Our main findings are listed as follows:

1. $T$ values are spatially heterogeneous, and a minimum of three criteria should be considered instead of only one when investigating the carbonate areas of southern China. Apparently, the "one region, one $T$ value" concept might not be applicable to this region.

2. $T$ value is proportionate to the amount of argillaceous material, which determines the surface soil thickness in the formations. The HC, CI and CA areas have $T$ values of 20,50 and $100 \mathrm{t} /\left(\mathrm{km}^{2} \mathrm{a}\right)$, and are respectively extremely, severely and moderately sensitive to soil erosion.

3. The generation of KRD land is unrelated to $T$ value, although this value reflects erosion sensitivity. Erosion risk depends strongly on the relationship between RL and $T$ value instead of on erosion intensity or the $T$ value itself. If RL $>>T$, then the risk is high despite the low RL. On the contrary, if $\mathrm{RL}<<T$, then the soil is safe despite the high RL.

In summary, we first report the following discoveries. The $T$ values are spatially heterogeneous, and a minimum of three criteria should be considered instead of only a single criterion in karst areas. Our findings disprove the old "one region, one $T$ value" concept. Secondly, we proposed a new viewpoint, which states that in karst regions, a large soil erosion modulus does not correspond to severe soil erosion. Although the $T$ value can reflect soil sensitivity, this value cannot indicate soil erosion risk. Thus, a low $T$ value indicates that the local soil is highly sensitive; however, the soil erosion risk is not necessarily high. Therefore, this risk depends strongly on the ratio between RL and $T$ value instead of on erosion intensity or on $T$ value itself.

Given that the determination time of natural erosion and environmental background conditions is poorly understood, the research object, method and consideration factors of soil loss tolerance are different. Therefore, further efforts should focus on defining and specifying the connotation and research methods of natural erosion and soil loss tolerance, as well as comprehensively and systematically studying the natural erosion and soil loss tolerance in different types of soil and water loss.

Data availability. No data sets were used in this article.

Competing interests. The authors declare that they have no conflict of interest. 
Acknowledgements. This research work was supported jointly by the National Key Research Program of China (No. 2016YFC0502300, 2016YFC0502102, 2013CB956700 \& 2014BAB03B02), United Fund of karst science research center (No. U1612441), International cooperation research projects of the national natural science fund committee (No. 41571130074 \& 41571130042), Science and Technology Plan of Guizhou Province of China (No. 2012-6015 \& 2013-3190 \& 201742920512120000), Science and technology cooperation projects (No. 2014-3).

Edited by: M. Oliva

Reviewed by: two anonymous referees

\section{References}

Alexander, E. B.: Rates of soil formation: Implications for soil-loss tolerance, Soil Sci., 145 37-45, 1988.

Bai, X., Zhang, X., Long, Y., Liu, X., and Zhang, S.: Use of ${ }^{137} \mathrm{Cs}$ and ${ }^{210} \mathrm{~Pb}_{\text {ex }}$, measurements on deposits in a karst depression to study the erosional response of a small karst catchment in southwest china to land-use change, Hydrol Process., 27, 822-829, 2013.

Bazzoffi, P.: Soil erosion tolerance and water runoff control: minimum environmental standards, Reg. Environ. Change, 9, 169179, 2009.

Bhattacharyya, P., Bhatt, K. V., and Mandal, D.: Soil loss tolerance limits for planning of soil conservation measures in ShivalikHimalayan region of India, Catena, 73, 117-124, 2008.

Cao, J. H., Jiang, Z. C., Yang, D. S., Tong, L. Q., Pei, J. G., Luo, W. Q., and Yang, H.: Soil and water loss, desertification controlled by karst environment in Guizhou Karst region, Soil Water Conserv. China, 1, 20-23, 2009 (in Chinese).

Chai, Z. X.: Soil Erosion in Karst Area of Guangxi Autonomous Region, Mountain Research, 7, 255-260, 1989 (in Chinese).

Chen, L. J.: Study on the Amount of soil Allowed Loss for Forest Land, J. Soil Water Conserv., 7, 8-22, 1993 (in Chinese).

Chen, Q. B., Wang, K. Q., Qi, S., Sun, L. D., and Wu, X. W.: Soil Loss Tolerance of Sloping Field in Semi-arid Hilly-gully Area of Loess Plateau, B. Soil Water Conserv., 23, 1-4, 2003 (in Chinese).

Comino, J. R., Quiquerez, A., Follain, S., Raclot, D., Bissonnais, Y. L., Casalí, J., Giménez, R., Cerdà, A., Keesstra, S. D., Brevik, E. C., Pereira, P., Senciales, J. M., Seeger, M., Ruiz Sinoga, J. D., and Ries, J. B.: Soil erosion in sloping vineyards assessed by using botanical indicators and sediment collectors in the RuwerMosel valley, Agr. Ecosyst. Environ., 233, 158-170, 2016.

Debolini, M., Schoorl, J. M., Temme, A., Galli, M., and Bonari, E.: Changes in Agricultural Land Use Affecting Future Soil Redistribution Patterns: A case study in Southern Tuscany (Italy), Land Degrad Dev., 26, 574-586, 2013.

Drever, J. I. and Stillings, L. L.: The role of organic acids in mineral weathering, Colloids \& Surfaces A Physicochemical \& Engineering Aspects, 120, 167-181, 1997.

Duan, X. W., Xie, Y., and Liu, B. Y.: Soil loss tolerance in the black soil region of Northeast China, J. Geogr. Sci., 22, 737-751, 2012.

Feng, Z. G., Ma, Q., Li, S. P., Wang, S. J., Huang, W., Liu, J., and Shi, W. G.: Weathering Mechanism of Rock-Soil Interface in Weathering Profile Derived from Carbonate Rocks: Prelimi- nary Study of Leaching Simulation in Rock Powder Layer, Acta Geol. Sin., 87, 199-132, 2013.

Gessesse, B., Bewket, W., and Bräuning, A.: Model-Based Characterization and Monitoring of Runoff and Soil Erosion in Response to Land Use/Land Cover Changes in the Modjo watershed, Ethiopia, Land Degrad. Dev., 26, 711-724, 2014.

Hays, O. E. and Clark, N.: Cropping system that helps control erosion. USA: University of Wisconsin, Bull No. 452, 1941.

Hu, Y. C., Liu, Y. S., Wu, P. L., and Zou, X. P.: Rocky desertificationin Guangxi karst mounminous area: its tendency, formation causes and rehabilitation, Transactions of the Chinese Society of Agricultural Engineering, 24, 96-101, 2008.

Jiang, Z. C., Xie, Y. Q., Zhang, C., and Weng, J. T.: A projected protection scheme for the karst. Geological landscape in Xishan region, Beijing, Nat Resour., 6, 60-73, 1997 (in Chinese).

Keesstra, S., Pereira, P., Novara, A., Brevik, E. C., Azorin-Molina, C., Parras-Alcántara, L., Jordán, A., and Cerdà, A.: Effects of soil management techniques on soil water erosion in apricot orchards, Sci. Total Environ., 551-552, 357-366, 2016.

Klingebiel, A. A.: Soil factors and soil loss tolerance, in: Soil Loss Prediction, North and South Dakota, Nebraska, and Kansas, USA: Soil Conservation Service, United States Department of Agriculture, 1961.

Lan, L., Zhou, Z. H., and Liu, G. C.: The present situation and conceive of soil loss tolerance study, Adv. Earth Sci., 20, 65-72, 2005 (in Chinese).

Li, Y. B., Wang, S. J., Wei, C. F., and Long, J.: The spatial distribution of soil loss tolerance in carbonate area in Guizhou province, Earth Environ., 34, 36-40, 2006.

Ligonja, P. J. and Shrestha, R. P.: Soil Erosion Assessment in Kondoa Eroded Area in Tanzania using Universal Soil Loss Equation, Geographic Information Systems and Socioeconomic Approach, Land Degrad. Dev., 26, 367-379, 2013.

Liu, G. C., Li, L., Wu, L., Wang, G., Zhou, Z., and Du, S.: Determination of soil loss tolerance of an Entisol in Southwest China, Soil Sci. Soc. Am. J., 73, 412-417, 2009.

Liu, Q. M., Wang, S. J., Piao, H. C., and Ouyang, Z. Y.: The changes in soil organic matter in a forest-cultivation sequence traced by stable carbon isotopes, Aust. J. Soil. Res., 41, 1317-1327, 2003.

Luo, G. J., Wang, S. J., Bai, X. Y., Liu, X. M., and Cheng, A. Y.: Delineating small karst watersheds based on digital elevation model and eco-hydrogeological principles, Solid Earth, 7, 457468, doi:10.5194/se-7-457-2016, 2016.

Molla, T. and Sisheber, B.: Estimating soil erosion risk and evaluating erosion control measures for soil conservation planning at Koga watershed in the highlands of Ethiopia, Solid Earth, 8, 13-25, doi:10.5194/se-8-13-2017, 2017.

Nadalromero, E. and Regüés, D.: Geomorphological dynamics of subhumid mountain badland areas-weathering, hydrological and suspended sediment transport processes: a case study in the Araguás catchment (Central Pyrenees) and implications for altered hydroclimatic regimes, Prog. Phys. Geogr., 34, 123-150, 2010.

Novara, A., Keesstra, S., Cerdà, A., Pereira, P., and Gristina, L.: Understanding the role of soil erosion on $\mathrm{CO}_{2}-\mathrm{C}$ loss using ${ }^{13} \mathrm{C}$ isotopic signatures in abandoned mediterranean agricultural land, Sci. Total Environ., 550, 330-336, 2016. 
Pak, T., Butler, I. B., Geiger, S., Van Dijke, M. I. J., Jiang, Z., and Surmas, R.: Multiscale pore-network representation of heterogeneous carbonate rocks, Water Resour. Res., 52, 2016.

Pierce, F. J., Dowdy, R. H., and Larson, W. E.: Soil productivity in the Corn belt: An assessment of erosion's long-term effects, J. Soil Water Conserv., 39, 131-136, 1984.

Pierce, F. J., Larson, W. E., and Dowdy, R. H.: Productivity of soils: Assessing long-term changes due to erosion, J. Soil Water Conserv., 38, 39-44, 1983.

Pretorius, J. R. and Cooks, J.: Soil Loss Tolerance Limits: An Environmental Management Tool, Geol. J., 19, 67-75, 1989.

Shui, J. G., Ye, Y. L., Wang, J. H., and Liu, C. C.: Regularity of Erosion and Soil Loss Tolerance in Hilly Red-Earth Region of China, J. Integr. Agr., 36, 179-183, 2003.

Skidmore, E. L.: Soil loss tolerance, in: Determinants of Soil Loss Tolerance, American Society of Agronomy, ASA Special Publication No. 45, 87-94, 1982.

Tian, Y. C., Wang, S. J., Bai, X. Y., Luo, G. J., and Xu, Y.: Tradeoffs among ecosystem services in a typical Karst watershed, SW China, Sci. Total Environ., 1297, 566-567, 2016.

Wang, S. J., Ji, H. B., Ouyang, Z. Y., Zhou, D. Q., Zheng, L. P., and Li, T. Y.: Preliminary study on weathering and pedogenesis of carbonate rock, Sci. China Ser. D., 29, 441-449, 1999 (in Chinese).
Wang, S. J., Liu, M., and Zhang, D. F.: Karst rocky desertification in southwestern China: Geomorphology, landuse, impact and rehabilitation, Land Degrad Dev., 15, 115-121, 2004.

Wang, Z., Johnson, D. A., Rong, Y., and Wang, K.: Grazing effects on soil characteristics and vegetation of grassland in northern China, Solid Earth, 7, 55-65, doi:10.5194/se-7-55-2016, 2016.

Wei, Q. P.: Soil Erosion in Karst Region of South China and Its Control, Res. Soil Water Conserv., 4, 72-76, 1996 (in Chinese).

William, L. and Smith, R. M.: A conservation definition of erosion tolerance, Soil Sci., 97, 183-186, 1964.

Wischmeier, W. H. and Smith, D. D.: Predicting Rainfall Erosion Losses from Cropland East of the Rocky Mountains: a guide to conservation planning, 1965.

Yang, C. Q., Cai, Q. G., and Fan, H. M.: Process of Soil Loss Tolerance Research-in the Phaeozem Region of Northeast China, Res. Soil Water Conserv., 11, 66-96, 2004 (in Chinese).

Yuan, Z. K., Zhu, G., Tian, D. L., Yuan, H. B., Zhang, C. M., and Liu, W. R.: Process of Loss of Soil and Water in Red Soil and Purple Soil Areas of Recovering Plants, J cent south forest univ., 25, 1-7, 2005.

Zhang, T. F., Cui, Z. N., Qian, Y. X., Xie, S. Y., and Bao, Z. Y.: Dissolution Kinetic Characteristics of Ordovician Marine Carbonate in Central Tarim Basin, Geol. Sci. Technol. Info., 26, 19-25, 2007. 